\title{
Volcano-Tectonic Interactions as Triggers of Volcanic Eruptions
}

\author{
Andrea Gabrieli ${ }^{1,2,3}$, Lionel Wilson ${ }^{1,2}$ and Stephen Lane ${ }^{1}$ \\ ${ }^{1}$ Lancaster Environment Centre, Lancaster University, Lancaster LA1 4YQ, UK \\ ${ }^{2}$ Hawai’i Institute of Geophysics and Planetology, University of Hawai’i at Mānoa, 1680 \\ East-West Road, Honolulu, Hawai’i 96922 USA \\ ${ }^{3}$ Department of Geology and Geophysics, University of Hawai’i at Mānoa, 1680 East-West \\ Road, Honolulu, Hawai’i 96922 USA \\ Corresponding Author: gabrieli@higp.hawaii.edu
}

Surface displacements and edifice deformations at active volcanoes can occur when magma reservoirs begin to inflate as new magma enters them. Volcanoes are also subjected to a variety of external lithospheric stresses that are thought to be responsible for triggering volcanic unrest or modifying ongoing activity. However, despite many observations, it is uncertain whether these phenomena can actually interfere with magma chamber dynamics since it is not clear why some volcanoes are more subjected to these interactions than others. In order to determine whether external stresses interfere with volcanic activity, a viscoelastic 3D Finite Element Mogi-based model of Kīlauea volcano's magma chamber was implemented. First, the model was used to replicate an inflation cycle without external stresses. Its results were then compared with the ones obtained if the same model was subjected to tidal stress modulation and a strong $(\mathrm{Mw}=7.7)$ tectonic earthquake. The model showed that tidally-induced pressurization is not sufficiently large to modify the pressure in a $5 \mathrm{~km}$ deep volcanic magma chamber, but it suggested how the magma chamber pressure build-up rate can be influenced by tidal pressurization and thus why some volcanoes seem to experience tidal interferences more than others. Furthermore, the model's results suggested why magma chambers are about the same size as calderas both on the Earth and on other Solar System silicate planets. System. Finally, it was used to propose an explanation of why a short-lived eruption at Kīlauea volcano, Hawai'i, began 30 minutes after the 1975 magnitude $7.7(\mathrm{Mw})$ Kalapana earthquake.

Key words: volcanoes, eruption, trigger, stress, FEM, tides, earthquakes

\section{Introduction}

Volcano-tectonic interactions have only relatively recently started to be extensively investigated by geoscientists (Watt et al., 2008). There is evidence that earthquake activity is significantly correlated with volcanic eruptions both in time (Linde et al., 1998) and space for the far-field (200-800 km) (Lemarchand et al., 2007; Manga et al., 2006) and the near-field (Alam, 2004). Also there is a positive correlation between the size of earthquakes and both the V.E.I. index (Marzocchi et al., 2002) and the volume of erupted material (Walter et al., 2006; Walter, 2007) in volcanic eruptions. In particular, regional earthquakes may trigger volcanoes to erupt. Pinatubo's (Philippines) 1991 (Bautista et al., 1996) and Puyehue-Cordon Caulle's (Chile) 1960 (Lara et al., 2004) eruptions have all been related to some extent to strong 
regional earthquakes. In addition, it has been inferred that ongoing volcanic activity could be enhanced by tectonic earthquakes. For example, it was observed that two volcanoes on Java increased their activity after a Magnitude 6.4 offshore earthquake (Harris and Riepepe, 2007) and that volcanic tremor signals at Stromboli, Italy, were modified after tectonic earthquakes (Fattori Speranza et al., 2007).

Nevertheless, such volcano-tectonic interactions are still not entirely understood. In fact, there is much disagreement on the way tectonic earthquakes are linked to volcanoes. One of the most accepted reasons for dynamic triggering is an increased nucleation of bubbles (Manga and Brodsky, 2006). Moreover, some geoscientists stress that volcanic eruptions are mainly triggered by compressive stresses that act on the magma chamber (Nakamura, 1975; Nostro et al., 1998) and others emphasize that decompressive stresses are more important because they enable more magma to enter the chamber, inflating it (Bursik et al., 2003; Walter et al., 2006). Finally, Hill et al. (1994) cast doubt on the two previous hypotheses and suggest that compression-decompression cycles of seismic waves determine the formation of micro factures that facilitate the intrusion of dykes in the shallow crust.

However, earthquakes are not the only external lithospheric phenomena that have been considered as triggers of volcanic eruptions. The unloading of volcanic edifices because of volcanic landslides and deglaciation, lunisolar Earth and ocean tides, and deep atmospheric high-low pressure variations such as those related to typhoons, cyclones and hurricanes have been thought to play a role in triggering or modifying volcanic activity (Stein, 1999; Hill et al., 2002), providing that the volcano is “in a nearly critical state” (Schimozuru, 1987).

There are many examples showing that the displacement of a huge amount of rocks during a landslide can lead to an explosive decompression if the slide fault is deep enough to intersect the magma beneath the surface (Parfitt, 2008). Furthermore, although it is accepted that deglaciation causes unloading of both volcanic edifices (Maclennan et al., 2002) and the mantle, which in turn increases the melting rate of the rocks (Schimdt, et al., 2013) and modifies eruption rates and magma compositions (Pagli et al., 2008), whether lithospheric stresses related to ocean and Earth tides and atmospheric pressure changes are sufficiently large to affect volcanic states is still widely debated. The static stress drop of a strong tectonic earthquake may vary between $10^{6}$ and $10^{7} \mathrm{~Pa}$, whereas the tidal load stress is estimated to be 5 orders of magnitude smaller (Varga, 1995). Nevertheless, statistical analysis of the times of eruptive and seismic events conducted at Mount Saint Helens, U.S.A. (McNutt and Beavan, 1984), Stromboli and Etna, Italy (Johnson and Mauk, 1972; Sottili et al., 2007), Kīlauea, Hawai'i (Rydelek et al., 1988), Mayon, Philippines (Jentzsch et al., 2001) and on Jupiter's moon Io (Peale et al., 1979) suggested that a correlation with the tidal stress modulation might exist. There is also other evidence of rock rheology being affected by tides due to pore pressures (Kümpel, 1997). Furthermore, a significant correlation between all of the 52 historic Kîlauea volcano eruptions and the fortnightly Earth tide has been found (Dzurisin, 1980) and daily fluctuations of the level of the Halema'uma'u lava lake have been observed and linked to Earth tides (Jagger, 1924). Nonetheless, although a correlation was found, there is no evidence that tidal stresses may be responsible for triggering an eruption. Furthermore, the same correlation was not found at Mauna Loa volcano, Hawai'i, despite its proximity to Kîlauea (Schimozuru, 1987). However, if lunisolar Earth and ocean tides influenced the inner dynamics of the magma in the Hawaiian volcanoes or in any other terrestrial volcano, they would be significantly related to whether the magma chamber was highly pressurized (Shimozuru, 1987) and to the latitude of the volcano, because tidal stress is a function of latitude (Varga, 1995). 
All these phenomena have been studied in the last decade and many of the effects that they cause on volcanic systems have been described. Nevertheless, the physical mechanisms that rule such interactions are still uncertain. The main problem is that all these external pressure sources might play a role in triggering volcanic activity, providing that the volcano is "in a nearly critical state" (Schimozuru, 1987) and what "critical state" means quantitatively is not known. Therefore, a Finite Element Mogi-based model of Kīlauea volcano’s magma chamber was developed for this project to determine whether lithospheric stresses disturb the activity state of volcanoes by firstly determining the eruption-triggering "critical state" and secondly by analysing how external stresses might affect this value.

\section{Methods}

One of the most commonly monitored geophysical phenomena is deformation because modifications of the shape of the volcanic edifice are easily measured and generally indicate underground magma movements and pressure variations in the magma reservoir (Scandone and Giacomelli, 2004). If ground deformation due to a new magmatic intrusion is considered, the most common scenario is that the displacement measured at the surface starts as new magma begins to enter the plumbing system of the volcano and to fill the magma chamber. As soon as the pressure within the magma chamber is sufficiently high to cause a rupture in the surrounding country rock, a failure may occur and a new dyke may start to propagate causing a decrease of the pressure within the magma chamber and eventually a deflation of the whole volcanic edifice.

The rate and the extent of these ground deformations depend on many elements such as the geometry of the volcano, the rate of intrusion, and the depth of the magma reservoir. At Kîlauea volcano the average horizontal deformation rate measured with two GPS stations 8 $\mathrm{km}$ apart on opposite sides of the caldera (USGS, 2014) is 0.1 meters per year (Poland et al., 2012).

Based on the work of Yamakawa (1955), who applied elasticity theory to a spherical magma body, Mogi (1958) showed that the vertical and horizontal displacements of the ground surface could be related to the change in internal pressure of the chamber, $\Delta P$ and to the change in volume, $\Delta V$. Volume and pressure changes of the magma reservoir are linked together by the Mogi equations and in turn are linked to the crustal strength of the country rock (Newman et al., 2006). Consequently, this means that adopting a reasonable country rock rheology is extremely important for the current study. It was initially assumed that the total pressure of the magma that is responsible for inflating the magma chamber and causing surface displacement was comparable to the overall lithostatic pressure, otherwise rock failure leading to an eruption might occur.

In this project, the Mogi-Yamakawa model was used to develop a three dimensional viscoelastic deformation model for Kîlauea volcano (Poland et al., 2012). Kîlauea volcano is the youngest of five subaerial volcanoes that form the Big Island of Hawai'i. Its elliptical summit caldera measures $4.5 \times 3 \mathrm{~km}$ (Decker et al., 1987). Kîlauea displays two rift zones: the South-West and the East, which diverge from the summit caldera and extend subaerially for 35 and 125 kilometres, respectively. The East rift zone hosts the current eruption that started on January 3rd, 1983 (Decker et al., 1987). These two Rift Zones are zones of weaknesses that cause the southern flank of Killauea to move toward the ocean at a rate of several centimeters per year (Tilling et al., 2014). Strong tectonic earthquakes, like the 
magnitude $7.7\left(\mathrm{M}_{\mathrm{w}}\right)$ Kalapana earthquake of November $29^{\text {th }}$, 1975 , are often associated with this movement (Hawaiian Volcano Observatory, 1995; Nettles and Ekström, 2004).

Following the magma chamber modelling carried out by Newman et al. (2006) and Chen et al. (2009), in order to create a model of Kîlauea's magma chamber, the free Finite Element software Lisa v8.00 was chosen. The deep magma chamber dynamics analysis was conducted with a 1064 elements and 1225 nodes Mogi-derived 3D Finite Element Model. The volcanic area that was considered was a $80 \mathrm{~km}$ long, $10 \mathrm{~km}$ high and $70 \mathrm{~km}$ wide rectangular parallelepiped volume, which was set in a $x, y, z$ tridimensional Cartesian Coordinate System. Based on Cayol and Cornet (1998) and Bonaccorso and Davis (1999), the Young's modulus was set to $100 \mathrm{GPa}$ and the Poisson's ratio to 0.25 . In the centre of the region, there was an ellipsoidal magma chamber. A total chamber volume of $25 \mathrm{~km}^{3}$ was chosen to be consistent with most geophysical estimates of various parts of the Kîlauea magmatic system (Delaney et al., 1990; Johnson, 1995; Parfitt, 2004). The depth of the centre of the model magma chamber was chosen as $5 \mathrm{~km}$, implying that magma vesiculation processes are minimal (Decker et al., 1987). Around the position of the magma chamber, the grid of the Finite Element Model was denser (figure 1) to better calculate the final stress and shear stress maps. The grid is made of three types of cells: The cells are respectively $0.8,0.2$ and $0.025 \mathrm{~km}$ long and the smallest ones are used in and around the magma chamber so that the proper resolution is obtained to study stresses in the area surrounding the magma chamber. The shear stress was measured along two horizontal lines: the first one is the ground surface of the model (line 1) and the second one is tangent to the upper top of the ellipsoidal magma chamber (line 2) (figure 1).

\section{[Figure 1]}

The lithostatic pressure at the top of the chamber, treated as hydrostatic, is (Newman et al., 2006):

$P_{\text {lith }}=(d-a) \rho g$

where $\rho$ is the rock density, assumed to be $2800 \mathrm{~kg} / \mathrm{m}^{3}$ (Newman et al., 2006) and $a$ is the effective radius of the Mogi magma source. For $d=(5.00+1.25) \mathrm{km}=6.25 \mathrm{~km}, a=(\alpha+\beta+$ $\gamma) / 3=1.887 \mathrm{~km}$, and $g=9.81 \mathrm{~m} / \mathrm{s}^{2}$ the value of the lithostatic load is $P_{\text {lith }}=122.2 \mathrm{MPa}$. This value has to balance the average pressure of the volcanic magma chamber in the resting state that was previously estimated to be about $100 \mathrm{MPa}$ (Jaupart, 1987). Otherwise, if the magma chamber pressure exceeds the lithospheric pressure, an eruption might occur. Rock tests determined that the rupture strength of a basaltic country rock is $2.50 \mathrm{MPa}$ (Atkinson, 1984). Therefore, in accordance with the model of the Tianchi volcano of Changbai Shan, China developed by Chen et al. (2009), it was assumed that if the difference between the absolute pressure of the magma reservoir, $P_{\text {chamber }}$, and the lithospheric load pressure exceeds a shear stress of $2.50 \mathrm{MPa}$, failure of the country rock surrounding the magma chamber occurs and a dyke begins to propagate; the consequences of $\left(P_{\text {chamber }}-P_{\text {lith }}\right)$ being less than zero were not considered. It was assumed that the initial value of the difference between the magma chamber and the lithostatic load pressure was 0.4 MPa. This guaranteed that the volcano was in the so-called "resting state" (Chen et al., 2009).

To operate the model, the magma chamber was caused to inflate at time $t=0$ at a constant rate of $3 \mathrm{~m}^{3} / \mathrm{s}$, which is the average mantle inflow for the Hawaiian Hot Spot (Swanson, 1972; Dvorak and Dzurisin, 1993) (Figure 2). The magma chamber was kept inflating until the rupture strength of the basaltic country rock was reached. In order to assess whether external 
lithospheric stresses are able to modify volcanic activity, it was essential to determine at which point in time and space the rupture strength was reached within the basaltic country rock if no external stress was applied. After this, the external stresses were applied and the results were compared in order to determine whether any modification in the stress distribution occurred.

\section{[Figure 2]}

The following step was to assess whether and how an external stress might modify the inner dynamics of the magma chamber. The Earth tidal stress and the static stress drop of a strong tectonic earthquake were considered. Kîlauea is situated at 19 degrees north latitude. The tidal stress at this latitude was estimated to be close to $100 \mathrm{~Pa}$ (Varga et al., 1996). Since a $100 \mathrm{~Pa}$ variation is very small compared with the values of pressure within the magma chamber, it was chosen to apply this tidal stress only to the highly pressurized magma chamber. Therefore, the tidal stress was applied when the rupture strength in the country rock was about to be reached.

The final step was to assess whether a strong tectonic earthquake with a static stress drop of 10 MPa (Varga et al., 1995; Ma et al., 1999) was able to cause a measurable and significant pressure variation in the magma chamber with the Finite Element model. The effects of seismic P-waves were considered because S-waves (shear waves) do not propagate in fluid magma chambers. In order to apply a seismic perturbation to the current simulation, the mathematical description of the propagation of a P-wave was necessary. The general equation for seismic waves is:

$$
(\lambda+2 \mu) \nabla(\nabla \cdot \vec{u})-\mu \nabla \times \nabla \times \vec{u}=\rho \frac{\partial^{2} u}{\partial t^{2}}
$$

where $t$ is the time, $\lambda$ and $\mu$ are the two Lame's parameters, which depend on the physical properties of the rock, and $\rho$ is the rock density. The solution of this equation for P-waves describes waves that are characterized by a series of volumetric compressive-decompressive cycles. The simulation was run with two single P impulses: firstly, one decompression impulse was sent and secondly a compression impulse after the first one (figure 2). The speed of the two impulses in both cases was the speed of a P-wave propagating in a basaltic medium: $6 \mathrm{~km} / \mathrm{s}$ (Mavko, 2014). In accordance with the estimate of Varga et al. (1996) the estimated earthquake static stress drop used was $10^{7} \mathrm{~Pa}$.

\section{Results}

As the model magma chamber inflated at a constant rate, the pressure within it began to rise and the whole volcanic edifice started to deform with surface displacements becoming evident. The displacement after two years of inflation of the $25 \mathrm{~km}^{3}$ magma chamber modelled with LISA v8.00 subjected to a constant $3 \mathrm{~m}^{3} / \mathrm{s}$ input rate of magma is shown in Figure 3. The horizontal deformation rate of the model measured along the $\mathrm{x}$ axis at $4 \mathrm{~km}$ from the centre is $0.067 \pm$ $0.001 \mathrm{~m} / \mathrm{yr}$. Thus the total deformation rate between stations located at $4 \mathrm{~km}$ on either side of the summit is $0.134 \pm 0.004 \mathrm{~m} / \mathrm{yr}$. This value is comparable to the value of $0.1 \mathrm{~m} / \mathrm{yr}$ reported by Poland et al. (2012) for similarly-spaced stations.

[Figure 3] 
These deformation results show that the model is able to replicate in an effective way the inflation mechanism observed with geodetic techniques at Killauea volcano. The increasing pressure rate due to the magma entering the magma chamber from the mantle that was obtained with the model is $0.866 \mathrm{MPa}$ per year.

In order to assess whether external lithospheric stresses are able to modify volcanic activity, it is essential to determine at which point in time and space the rupture strength of $2.50 \mathrm{MPa}$ is reached within the basaltic country rock if no external stress is applied. After this, the external stresses can be applied and the results compared in order to determine whether any modification in the stress distribution occurs. For this reason, the distribution of the shear stress in the basaltic rocks surrounding the inflating magma chamber is considered. The result of the simulation is shown in figure 4. One shear stress peak was observed at the top of the magma chamber (figure 5) and two localized peaks of shear stress were observed at the surface (figure 6). The assumed $2.50 \mathrm{MPa}$ rupture strength of the basaltic country rock was first reached on the top boundary of the magma chamber after $2.37 \pm 0.05$ years from the beginning of the inflation. Therefore, according to the model, the region of the country rock surrounding the chamber that is most likely to rupture is its top. This result is in accordance with those of the Long Valley Caldera dynamics simulations by Newman et al. (2006) and of the model of Tianchi volcano in Changbai Shan, China (Chen et al., 2009).

\section{[Figure 4]}

\section{[Figure 5]}

\section{[Figure 6]}

The following step was to assess whether and how an external stress might modify the inner dynamics of the magma chamber. Firstly Earth tides and secondly strong tectonic earthquakes were considered. Kîlauea is situated at 19 degrees latitude North. The absolute value of the tidal stress modulation at this latitude was estimated to be close to $100 \mathrm{~Pa}$ (Varga et al., 1996). The angle of tilt between the normal to the ground line and the tidal stress direction is 19 degrees.

Since a 100 Pa variation is very small compared with the values of pressure within the magma chamber, it is chosen to apply such tidal stress only to a highly pressurized magma chamber because in this condition it is more likely to determine whether Earth tides may interfere with magma chamber dynamics (Sottili et al., 2007). Therefore, the tidal stress is applied when the rupture strength in the country rock is about to be reached. However, no significant changes in pressure in the magma chamber were determined.

The next step was to assess whether a tectonic earthquake with a static stress drop of $10 \mathrm{MPa}$, like the 1975 Kalapana earthquake, might disturb volcanic states. When the model magma chamber was subjected to the simulated earthquake, an instantaneous dynamic stress change of $1.20 \pm 0.01 \mathrm{MPa}$ in the top region of the magma chamber and a decrease of $0.003 \mathrm{MPa}$ at its edges occurred. These results are shown in the stress map of figure 7.

[Figure 7]

\section{Discussion and analysis}


If no external stress is applied to the volcano and the $25 \mathrm{~km}^{3}$ magma chamber is subjected to a constant magma input rate of $3 \mathrm{~m}^{3} / \mathrm{s}$, the model shows that the rupture strength in the country rock of $2.50 \mathrm{MPa}$ is reached after $2.37 \pm 0.05$ years from the beginning of the inflation when the excessive pressure in the chamber was $0.4 \mathrm{MPa}$. This time is in accordance with the average interval between two successive eruptions at Kîlauea volcano that is about 1-2 years (HVO, 2014). The computed change in volume due to the inflation was 0.027 cubic kilometres and the increasing pressure rate due to the magma coming into the magma chamber from the mantle that was obtained with the model is $0.866 \mathrm{MPa}$ per year. The total horizontal surface displacement that was obtained by the model $(0.134 \pm 0.004$ meters per year) during the magma inflation period at the rate of the Hawaiian hot spot was in accordance with the geodetic measurement performed by the two Hawaiian Volcano Observatory GPS stations at Kîlauea (0.1 meters per year) (USGS, 2014).

The two specific peaks of stress between three and four kilometres from the centre of the model emphasize that during an inflation event the distribution of the shear stress at the surface is more concentrated above the edges of the magma chamber rather than its center. This distinctive distribution was observed also by Gudmundsson, 1988 and Chen et al., 2009. On the Earth it is observed that calderas are about the same size as the magma chambers beneath them (Parfitt et al., 2008). For this reason, it is proposed that this particular distribution of shear stress may contribute to the formation of the caldera itself. The filling of the magma chamber and the inflation of the whole volcanic edifice determine localised peaks of stress at the surface above the edges of the magma chamber. Moreover, deflation creates the same pattern, but reversed and quicker (i.e. characterized by increased stress) after an eruption. So, an inflation followed by a quicker deflation pattern, in combination with focused stress, would result in the creation of zones of weaknesses and faults in the volcanic edifice that may facilitate the collapse of the edifice and the formation of a caldera along these zones of weaknesses (figure 8).

No significant correlation between tidal stress and magma chamber dynamics was found. It could be inferred that the tidal stress is not able to modify the activity of the volcano because of the great depth of the magma chamber. However, the stress does not simply scale with depth because it is determined by the strength of the rocks. Furthermore, if the magma was shallower it would be contained in a dike or a sill and the geometry of the tip of a dike or a sill is different from that of the wall of a magma chamber that was considered in this simulation. So, the stress needed to cause the failure would be different: possibly smaller, but it is not possible to quantify how much smaller with the current model. Furthermore, this type of investigation at shallow depths would also have to take into account vesiculation processes, which were not considered in this project. Consequently, additional studies with other computer models considering other geometries and scenarios at different depths would be necessary to better understand these issues and solve the contradictions in the literature that were highlighted earlier.

However, in case lunisolar Earth tides were more relevant at shallow depths it should be noticed that the failure of the country rock may not just simply occur only with the maximum externally-induced tidal stress. In fact, two cases have to be distinguished: when the magmatic pressure build-up over time $d P / d t$ is larger than the external pressure change $d P_{\text {ext }} / d t$ and vice versa. As long as the pressure build-up $d P / d t$ is larger than the external pressure change $d P_{\text {ext }} / d t$, an eruptive event is time-independent and an eruption could occur at any time within the diurnal cycle (figure 9a) 
Conversely, from a theoretical point of view, if the pressure build-up is smaller than the external pressure change, an eruption can only occur in limited and periodic time intervals that would be modulated mainly by the Earth tides (figure 9b). However, the time of the eruption may not necessarily be linked to the time in which the maximum tidal stress is reached, as the sketch in figure 9c proves. In fact, in figure 9c the eruption is triggered a few hours after the minimum tidal stress occurred. So, eruptions may be tidally triggered not only when the maximum stress is reached, but also if the gradient of tidal stress is positive.

This idea may explain why some volcanoes seem more subjected to tidally induced pressurization than others. In fact, the simulation showed that the increasing pressure rate due to the magma coming in the magma chamber from the mantle, which is $0.866 \mathrm{MPa}$ per year, is slightly larger, but not significantly larger, than the tidal pressure variation at the surface. Therefore, Kîlauea, which presents a correlation between its eruptions and the fortnightly Earth tide (Dzurisin, 1980), is neither in the condition $d P_{\text {ext }} / d t<<d P / d t$ nor is it in the opposite one because neither of the two pressure rates is considerably larger than the other one. This result does not exclude the fact that Kîlauea may be influenced by tides, but neither does it explain why a significant statistical correlation between eruption and fortnightly Earth tide was observed. For this reason, additional studies considering also magma propagating at shallower depths in the two Rift Zones should be taken into account and carried out in the future. Statistical revision of the past studies may also be necessary.

The current simulation was conducted as a model of Kîlauea volcano. However, this theoretical reasoning concerning the times of the eruptions and the tides may also be applied to Mauna Loa to explain why the same correlation that was observed at Kîlauea was not found at Mauna Loa despite its vicinity to Kīlauea. In fact, Mauna Loa's bigger historical eruption rates imply that larger pressure variations characterize the volcano's activity (Decker et al., 1995). Therefore, Mauna Loa's pressure build-up variation is significantly larger than the external pressure variation induced by tidal modulation. Therefore, this result shows that eruptions at Mauna Loa are time independent from the tides and explains why a significant correlation between tides and eruption times was not found at Mauna Loa (Schimozuru, 1987). However, additional computer model studies specifically about this volcano should also be carried out.

A strong tectonic earthquake may cause a static stress drop up to $10 \mathrm{MPa}$ (Varga et al., 1996). The model suggests that an earthquake of such magnitude could produce an instantaneous dynamic stress change from the seismic waves of $1.20 \pm 0.01 \mathrm{MPa}$ in the top region of the magma chamber and a decrease of $0.003 \mathrm{MPa}$ at its edges. The model suggests that, at the normal inflation rate of $3 \mathrm{~m}^{3} / \mathrm{s}$, the magma chamber would take about half a year to increase its pressure by $1 \mathrm{MPa}$. Nonetheless, an earthquake could raise the pressure instantaneously. This suggests that a strong tectonic earthquake may trigger a volcanic eruption.

An example of this is the November $29^{\text {th }} 1975$ magnitude $7.7\left(\mathrm{M}_{\mathrm{w}}\right)$ tectonic earthquake that struck the Kapalana area in the Puna district of the Big Island of Hawai'i. The USGS reported that at that time Killauea was expected to erupt soon as all the geodetic techniques used at Kîlauea showed that the volcano had been inflating steadily since its last eruption in December 1974. Furthermore, the amount of inflation had reached a level very close to that of other recent eruptions. So, the volcano was in a highly pressurized condition like the magma chamber of the computer simulation. Based on the results of the model, the November $29^{\text {th }}$ 
tectonic earthquake triggered the eruption. In fact, the eruption would probably have happened soon, but the stress change due to the earthquake was the final ingredient to induce the volcano to erupt. The eruption was of small volume and of short duration and this suggests that the magma might not have been able to be erupted at the surface under its own buoyancy without an external trigger.

Furthermore, the eruption occurred in the caldera, which is where the model predicts it to be, rather than on the East Rift Zone, where most eruptions are. Also, the time at which the eruption occurred strengthens the trigger hypothesis. The surface eruption began 30 minutes after the earthquake. The model highlighted that the pressure variation due to an earthquake is essentially instantaneous. This time gap of half an hour is presumably the time needed for magma to travel to the surface in a propagating dyke. The magma flow speed in dykes of the size seen in the Hawaiian volcanoes is of order of 1-2 meters per second (Decker et al., 1987). So, in 30 minutes, i.e. 1800 seconds, magma could travel $1800-3600 \mathrm{~m}$, which is a plausible distance from the reservoir to the surface.

\section{Conclusion}

A viscoelastic 3D Finite Element Mogi-based model was used to replicate a well-known longterm inflation cycle at Kîlauea volcano without external stresses and with both tidal and earthquake-induced stresses.

Firstly, the model showed that tidally induced pressurization is not relevant at the depth at which the magma chamber was set and is not sufficiently large to trigger a volcanic eruption, or to modify the volcanic resting state. It is proposed that if the absolute value of the tidal external pressure modulation exceeds the internal pressure increase, an eruption could only occur in limited and periodic time intervals that would be mainly modulated by the Earth tides, but not necessarily at the time of the maximum tidal stress. However, new studies dealing with different geometries of magma intrusions and rift zones are recommended.

Moreover, the model's results suggested why magma chambers are about the same size of calderas. In fact, the shear stress measured at the surface of the model pointed out the presence of localised peaks of stress between three and four kilometres from the centre of the model. In these regions, the difference in terms of stress between the edges and the centre of the caldera is about $20 \mathrm{kPa}$. This characteristic distribution of shear stress at the edges of the caldera results in the creation of zones of weaknesses and faults in the volcanic edifice that may facilitate the collapse of the edifice and the formation of a caldera exactly along these zones of weaknesses once the pressure in the magma chamber begins to decrease because of an extrusion.

Finally, the model suggested also that a magnitude $7.7\left(\mathrm{M}_{\mathrm{w}}\right)$ earthquake can produce an abrupt stress change in the top region of a magma chamber that can be sufficiently large to trigger an eruption. The results were used to propose that the small and short lived 1975 eruption at Kilauea volcano was actually triggered by the earthquake that struck the flanks of the volcano half an hour before the eruption occurred. In fact, the magma might not have been able to be erupted at the surface without an external trigger.

\section{References}


Alam, M., Kimura, M. (2004) Statistical analysis of time-distance relationship between volcanic eruptions and great earthquakes in Japan. Earth, Planets and Space 65, 179-192

Bautista, B.C., Bautista, L.P., Stein, R.S., Barcelona, E.S., Punongbayan, R.S., Laguerta, E.P., Rasdas, A.R., Ambubuyog, G., Amin, A.Q. (1996) Relationship of regional and local structures to Mount Pinatubo activity. Published in: Newhall, C.G., Punongbayan, R.S. Fire and mud. University of Washington Press, 351-370

Bonaccorso, A., Davis, P.M., 1999. Models of ground deformation from vertical volcanic conduits with application to eruptions of Mount St. Helens and Mount Etna. J. Geophys. Res. 104, 10531-10542.

Bursik, M., Renshaw, C., McCalpin, J., Berry, M. (2003) A volcano-tectonic cascade: activation of range front faulting and eruptions by dyke intrusion, Mono Basin-Long Valley Caldera, California. Journal of Geophysical Research, B, Solid Earth and Planets 108, 2393

Cayol, V., Cornet, F.H., 1998. Effects of topography on the interpretation of the deformation field of prominent volcanoes — application to Etna. Geophys. Res. Lett. 25, 1979-1982.

Chen, H.X., Hong, H.J., Liu, H. (2009) Volcano-tectonic interaction and its relation with the state of volcanic activity. Chinese Journal of Geophysics 52, 596-603

Decker, R.W., Klein, F.W., Okamura, A.T., Okubo, P.G. (1995) Forecasting eruptions of Mauna Loa Volcano, Hawai'i. U.S. Geological Survey

Decker, R.W., Wright, T., Stauffer, P.H. (1987) Volcanism in Hawai’i: Volume I. United States Government Printing Office, Washington

Decker, R.W., Wright, T., Stauffer, P.H., (1987) Volcanism in Hawai'i: Volume II. United States Government Printing Office, Washington

Delaney, P.T., Fiske, R.S., Miklius, A., Okamura, A.T., Sako, M.K. (1990) Deep magma body beneath the summit and rift zones of Kilauea Volcano, Hawaii. Science 247, 1311-1316.

Dvorak, J.J., Dzrurisin, D. (1993) Variations in magma supply rate at Kilauea volcano, Hawaii. Journal of Geophysical Research 98 (B12), 22255-22268, doi:10.1029/93JB02765

Dzurisin, D. (1980) Influence of fortnightly Earth tides at Kilauea Volcano, Hawaii. Geophysical Research Letters 7, 925-928

Fattori Speranza, F., Carniel, R. (2007) Structural changes of volcanic tremor at Stromboli volcano. Journal of Volcanology and Geothermal Research 171, 103-117

Fiske, R.S., Jackson E.D. (1972) Orientation and growth of Hawaiian volcanic rifts: the effect of regional structure and gravitational stresses. Proceedings Royal Society, London 329, 299-326

Gudmundsson, A., (1988). Formation of collapse calderas. Geology v.16, p. 808-810

Harris, A.J.L., Riepepe, M. (2007) Regional earthquake as a trigger for enhanced volcanic activity: evidence from MODIS thermal data. Geophysical Research Letters 34: L02304

Hawaiian Volcano Observatory (1995) The Kalapana Earthquake of 1975. [Online], Available at: <http://hvo.wr.usgs.gov/volcanowatch/archive/1995/95_11_24.html>, [accessed 24 July 2014]

Hawaiian Volcano Observatory (2014) Kilauea: perhaps the World's most active volcano. [Online], Available at: <http://hvo.wr.usgs.gov/kilauea/>, [accessed 24 July 2014]

Hill, D.P., Jhonston, M.J.S., Langbein, J.O., Behr, J. (1994) The role of crustal fluids in the triggered response of Long Valley Caldera to the $M=7.3$ Landers, California, earthquake. USGS 
Hill, D.P., Pollitz, F., Newhall, C. (2002) Earthquake-volcano interactions. Physics Today 55, 41-47

Jaupart, C. (1987) Magma ascent at shallow levels. Published in: Decker, R.W., Wright, T., Stauffer, P.H. Volcanism in Hawai'i: Volume II. United States Government Printing Office, Washington.

Jentzsch, G., Haase, O., Kroner, C., Winter, U. (2001) Mayon volcano, Phylippines: some insight into stress balance. Journal of Volcanology and Geothermal Research 109: 205-217

Johnson, D.J. (1995) Molten core model for Hawaiian rift zones. Journal of Volcanology and Geothermal Research 66, 27-35

Johnston, M.J.S., Maulk, F.J. (1972) Earth tides and the triggering of eruptions from Mt. Stromboli, Italy. Nature 239, 266-267

Lara, L.E., Naranjo, J.A., Moreno, H. (2004) Rhyodacitic fissure eruption in Southern Andes (Cordon Caulle; 40.5 degrees S) after the 1960 (Mw: 9.5) Chilean earthquake: a structural interpretation. Journal of Volcanology and Geothermal Research 138, 127-138

Lemarchand, N., Grasso, J.R. (2007) Interactions between earthquakes and volcano activity. Geophysical Research Letters 34, L24303.

Linde, A.T., Sacks, I.S. (1998) Triggering of volcanic eruptions. Nature 395, 888-890

Lockwood, J.P., Lipman, P.W. (1987) Holocene eruptive history of Mauna Loa volcano. Published in: Decker, R.W., Wright, T., Stauffer, P.H. Volcanism in Hawai'i: Volume I. United States Government Printing Office, Washington.

Ma, K-F., Kanamori, H., Satake, K. (1999) Mechanism of the 1975 Kalapana, Hawaii, earthquake inferred from tsunami data. Journal of Geophysical Research 104: 13153-13167

Maclennan, J., Jull, M., McKenzie, D., Slater, L., Grönvold, K. (2002) The link between volcanism and deglaciation in Iceland. American Geophysical Union

Manga, M., Brodsky, E. (2006) Seismic triggering of eruptions in the far field: volcanoes and geysers. Annual Review of Earth and Planetary Sciences 34, 263-291

Marzocchi, W., Casarotti, E., Piersanti, A. (2002) Modelling the stress variations induced by great earthquakes on the largest volcanic eruptions of the $20^{\text {th }}$ century. Journal of Geophysical Research B: Solid Earth 107, ESE13-1-ESE13-8

Mavko, G. (2014) Parameters that influence seismic velocity: conceptual overview of rock and fluid factors that impact seismic velocity and impedance. Stanford Rock Physics Laboratory. [Online] Available at: <https://pangea.stanford.edu/courses/gp262/Notes/8.SeismicVelocity.pdf>, [Accessed on 7 July 2014]

McNutt, S.R., Beavan, R.J. (1984) Patterns of earthquakes and the effect of the solid Earth and ocean load tides at Mount Saint Helens prior to the May 18, 1980 eruption. Journal of Geophysical Research 89(B5), 3075-3086.

McTigue, D.F. (1987) Elastic stress and deformation near a finite spherical magma body: resolution of the point source paradox. Journal of Geophysical Research 92, 12931-12940

Mogi, K. (1958) Relations between the eruptions of various volcanoes and the deformations of the ground surfaces around them. Bulletin of the Earthquake Research Institute, University of Tokyo, vol 36, 99-134

Nakamura, K. (1975) Volcanic eruption caused by squeeze up of magma due to compressive tectonic stress. Bulletin of the Volcanological Society of Japan 20, 116. 
Nettles, M., Ekström, G. (2004) Long-period source characteristics of the 1975 Kalapana, Hawaii, Earthquake. Bulletin of the Seismological Society of America 94: 422-429

Newman, A.V., Dixon, T.H., Gourmelen, N. (2006) A four-dimensional viscoelastic deformation model for Long Valley Caldera, California, between 1995 and 2000. Journal of Volcanology and Geothermal Research 150, 244-269, doi:10.1016/j.jvolgeores.2005.07.017

Nostro, C., Stein, R.S., Cocco, M., Belardinelli, M.E., Marzocchi, W. (1998) Two-way coupling between Vesuvius eruptions and southern Appennine earthquakes, Italy, by elastic stress transfer. Journal of Geophysical Research B: Solid Earth 103, 24487-24504

Pagli, C., Sigmundsson, F. (2008) Will present day glacier retreat increase volcanic activity? Stress induced by recent glacier retreat and its effect on magmatism at the Vatnajökull ice cap, Iceland. Geophysical Research Letters 35, L09304

Parfitt, E.A., Peacock, D.C.P. (2000) Faulting in the South Flank of Kilauea Volcano, Hawai'i. Journal of Volcanology and Geothermal Research 106, 265-284

Parfitt, E., Wilson, L. (2008) Fundamentals of physical volcanology. Blackwell Publishing

Peale, S.J., Cassen, P., Reynolds, R.T. (1979) Melting of Io by tidal dissipation. Science 203, 892-894

Poland, M.P., Mikilius, A., Sutton, A.J., Thornber, C.R. (2012) A mantle-driven surge in magma supply to Kilauea volcano during 2003-2007. Nature. doi:10.1038/ngeo1426

Rydelek, P.A., Davis, D.M., Koyanagi, P.Y. (1988) Tidal triggering of earthquake swarms at Kilauea volcano, Hawaii. Journal of Geophysical Research 93(B5), 4401-4411

Scandone, R., Giacomelli, L. (2004) Vulcanologia. Principi fisici e metodi di indagine. Liguori

Schimdt, P., Lund, B., Hieronymus, C., Maclennan, J., Árnadóttir, T., Pagli, C. (2013) Effects of present-day deglaciation in Iceland on mantle melt production rates. Journal of Geophysical Research: Solid Earth 118, 3366-3379

Schimozuru, D. (1987) Tidal effects on Hawaiian volcanism. Published in: Decker, R.W., Wright, T., Stauffer, P.H. Volcanism in Hawai'i: Volume II. United States Government Printing Office, Washington.

Sottili, G., Martino, S., Palladino, D.M., Paciello, A., Bozzano, F. (2007) Effects of tidal stresses on volcanic activity at Mount Etna, Italy. Geophysical Research Letters, vol. 34 L01311, doi:10.1029/2006GL028190

Stein, R.S. (1999) The role of stress transfer in earthquake occurrence. Nature 402, 605-609.

Swanson, D.A. (1972) Magma supply rate at Kilauea volcano, 1952-1971. Science 175, no. 4018, 169-170, doi: 10.1126/science.1754018.169

Swanson, D.A., Duffield, W.A., Fiske, R.S. (1976) Displacement of the south flank of Kilauea Volcano: the result of forceful intrusion of magma into the rift zones. U.S. Geological Survey Professional Paper 963.

Tilling, R.I., Kauahikaua, J.P., Brantley, S.R., Neal, C.A. (2014) The Hawaiian Volcano Observatory-A Natural Laboratory for Studying Basaltic Volcanism. Published in: Poland, M.P., Takahashi, T.J., Landowski, C.M. Characteristics of Hawaiian Volcanoes. U.S. Geological Survey Professional paper 1801, 2014

USGS (2013) Mount Saint Helens: 1980 cataclysmic eruption. [Online]. Available at: <http://volcanoes.usgs.gov/volcanoes/st_helens/st_helens_geo_hist_99.html>, [accessed 22 July, 2014]

USGS (2014) Kilauea volcano, Hawai'i: deformation. [Online] Available at: <http://hvo.wr.usgs.gov/kilauea/update/deformation.php>, [Accessed 14 July 2014] 
Varga, P., Grafarend, E. (1996) Distribution of the lunisolar tidal elastic stress tensor components within the Earth's mantle. Physics of the Earth and Planetary Interiors 93, 285-297

Walter, T.R. (2007) How a tectonic earthquake may wake up volcanoes: stress transfer during the 1996 earthquake-eruption sequence at Karymsky Volcanic Group, Kamchatka. Earth and Planetary Science Letters 264, 347-359

Walter, T.R., Amelung, F. (2006) Volcano-earthquake interaction at Mauna Loa volcano, Hawai'i. Journal of Geophysical Research 111.

Walter, T.R., Amelung, F. (2007) Volcanic eruptions following $\mathrm{M} \geq 9$ megathrust earthquakes: implications for the Sumatra-Andaman volcanoes. Geology 35, 539-542

Watt, S.F.L., Pyle, D.M., Mather, T.A. (2008) The influence of great earthquakes on volcanic eruptions rate along the Chilean subduction zone. Earth and Planetary Science Letters 277, 399-407

Yamakawa, N. (1955) On the strain produced in a semi-infinite elastic solid by an interior source of stress. Journal of the Seismological Society of Japan, 8: 84-98

\section{List of figure captions}

Figure 1. Cross section of the volcanic region modeled. The grid is made of three types of cells, respectively 0.8 , 0.2 and $0.025 \mathrm{~km}$ long. The smallest ones are used in and around the magma chamber to better study the stress distribution. The two lines indicate where the shear stresses were measured. The surface shear stress was measured along line 1 and the tangent to the magma chamber shear stress was measured along line 2 . The $z$ axis points out of the paper.

Figure 2. The constant input of magma at a rate of $3 \mathrm{~m}^{3} / \mathrm{s}$ is shown by green arrows in the above cross section of the volcanic area that was considered. The base of the system is fixed and is not able to move. This is indicated by the red marks at the bottom of the model. The other boundaries are free. The compression and the decompression components of the P-wave used to simulate the earthquake are also shown and are displayed in the blue box. Both components travelled at $6 \mathrm{~km} / \mathrm{s}$.

Figure 3. Displacement after two years of inflation. The maximum surface displacement occurred at $5 \mathrm{~km}$ respectively on the left and on the right of the magma chamber.

Figure 4. Cross section of the volcanic area. The distribution of the vertical shear stress in the basaltic rocks surrounding the inflating magma chamber is shown. The magma chamber is filled with molten liquid rock that does not support any shear stress. For this reason it is displayed in white.

Figure 5. The vertical shear stress measured in the basaltic country rock along the horizontal line (line 2 of figure 1) that is tangent to the upper top of the ellipsoidal magma chamber at five different time intervals. $T$ $=2.37$ years is the estimated necessary time to reach the rupture strength and eventually the failure of the upper part of the magma chamber and the propagation of a dyke.

Figure 6. The vertical shear stress measured at the surface along the horizontal line (line 1 of figure 1 ) that divides the caldera into two equal parts. Two distinct peaks are evident. This result indicates that the distribution of the shear stress at the surface is more concentrated on the edges of the caldera rather than in its centre. The difference between the edges and the centre of the caldera is about $20 \mathrm{kPa}$.

Figure 7. The dynamic stress map of the magma chamber is shown during the propagation of the earthquake. The top, central region of the magma chamber increased its pressure of $1.2 \mathrm{MPa}$ during the propagation of the seismic P-wave.

Figure 8. Comparison of the zoom of the cross section of figure 4 obtained with the model and a sketch of a magma chamber with the location of the summit caldera. 
Figure 9. Qualitative sketch showing tidally-induced pressurization. If the magmatic pressure build up $d P / d t$ is significantly larger than the tidal modulation $d P_{\text {ext }} / d t$, an eruption can occur at any time within the diurnal cycle (A). Whereas if the pressure build-up $d P / d t$ is lower than the external pressure change $d P_{\text {ext }} / d t$, an eruption can only occur in limited and periodic time intervals that would be mainly modulated by the Earth tides (B, C).

\section{List of figures}

Figure 1 (below)

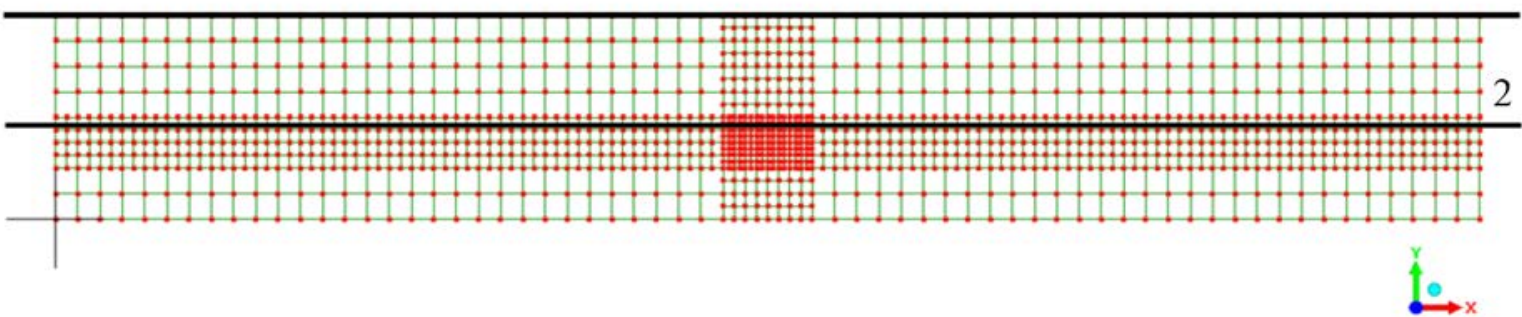

Figure 2

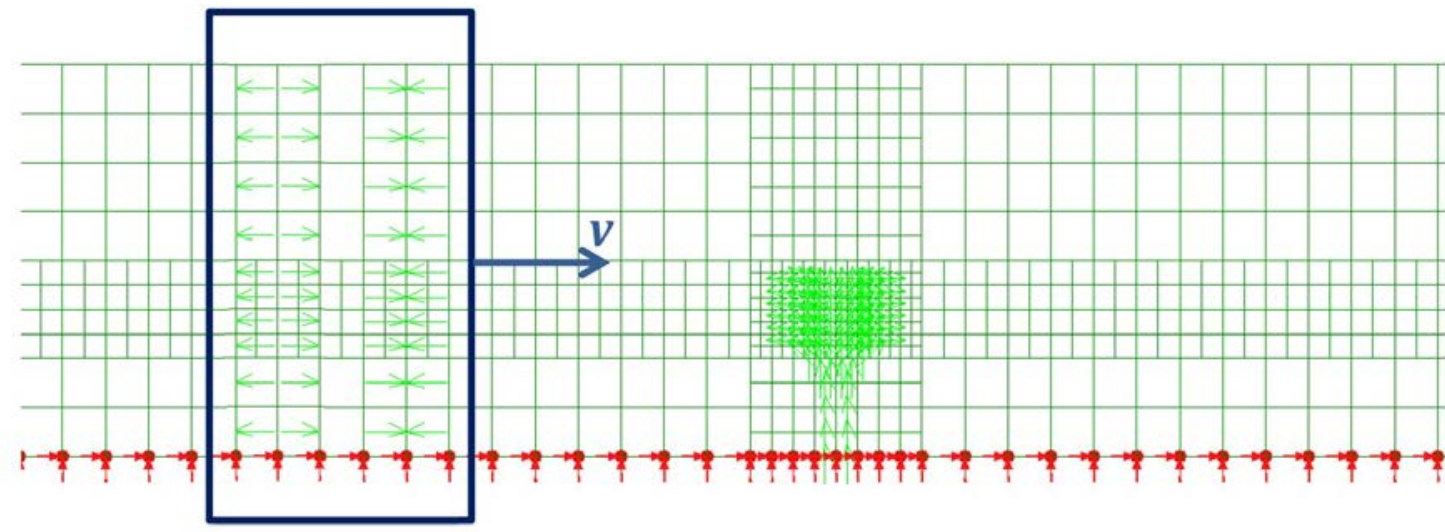

Figure 3 


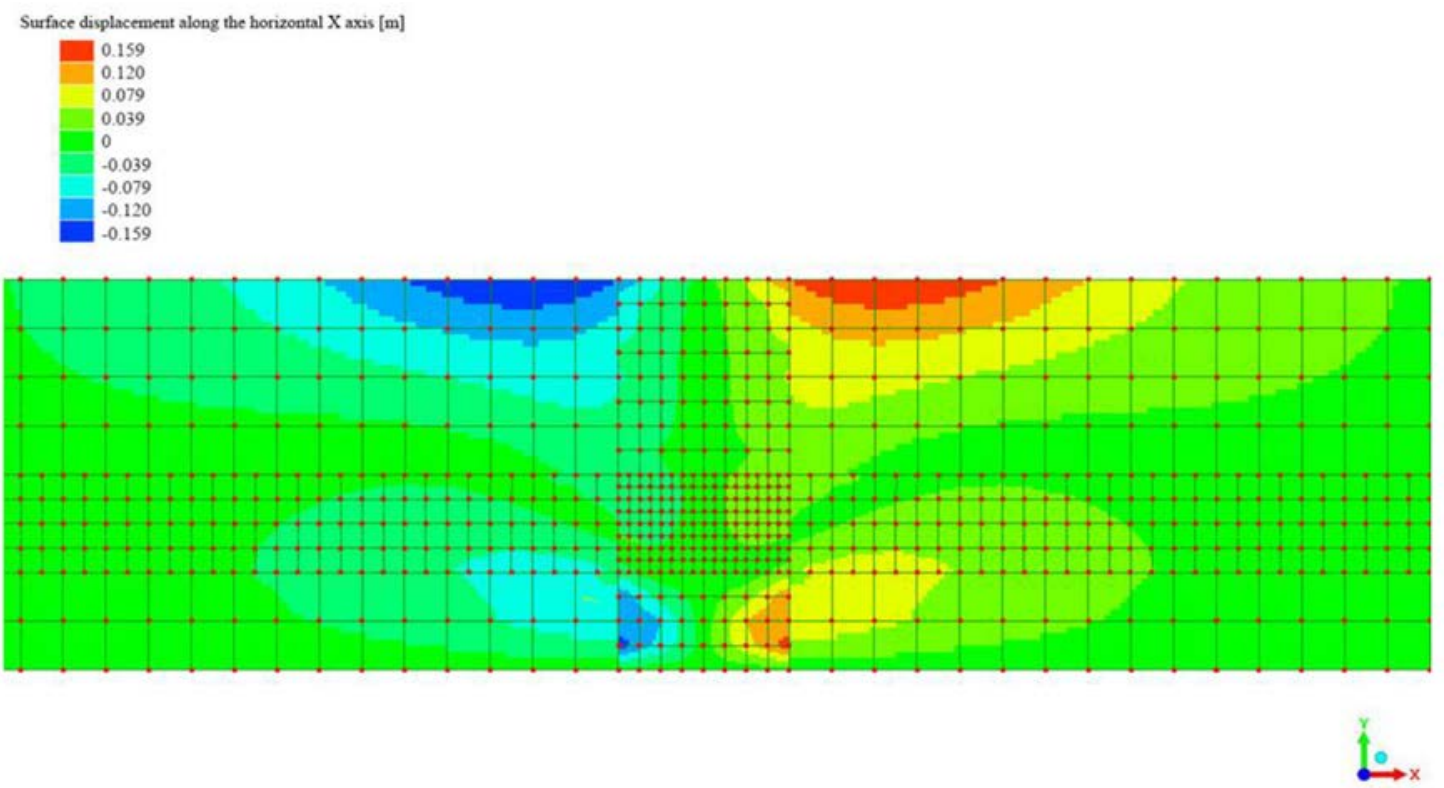

\section{Figure 4}

Shear Stress in MPa
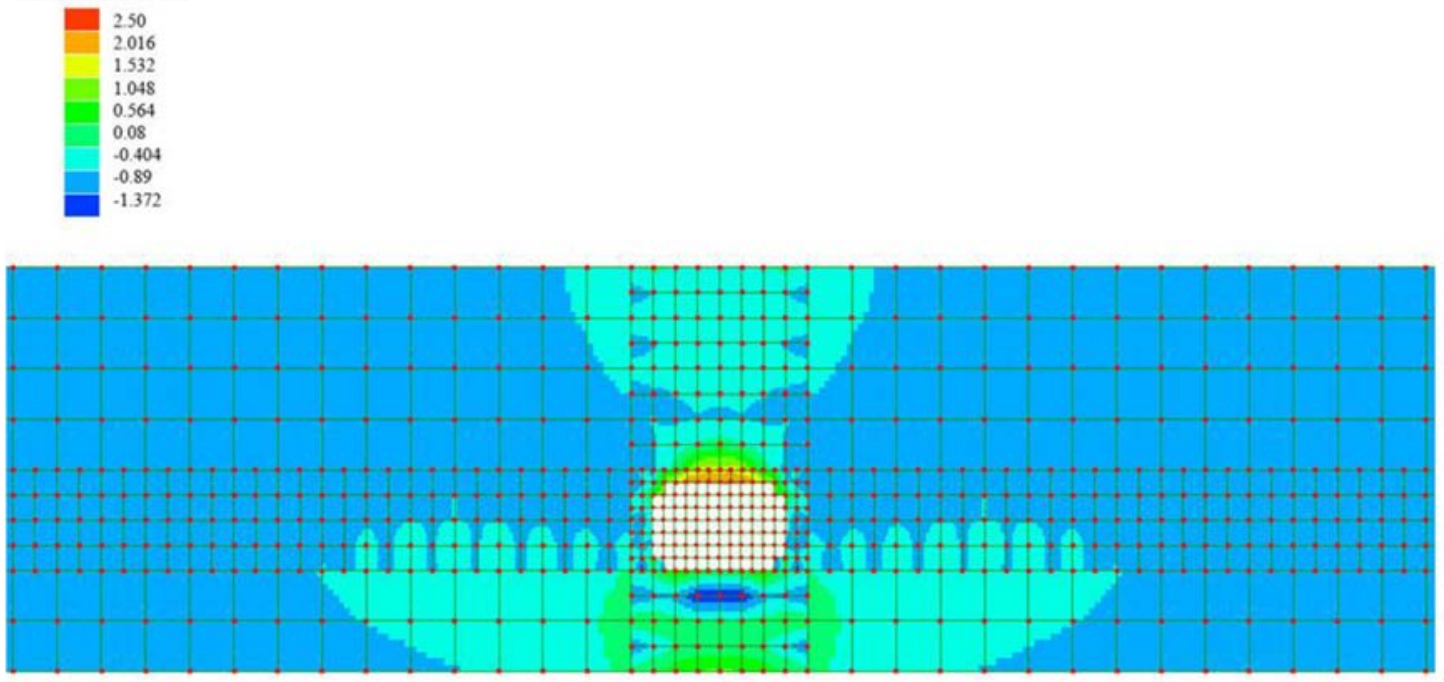

$\stackrel{\mathrm{L}}{\longrightarrow} x$

Figure 5 


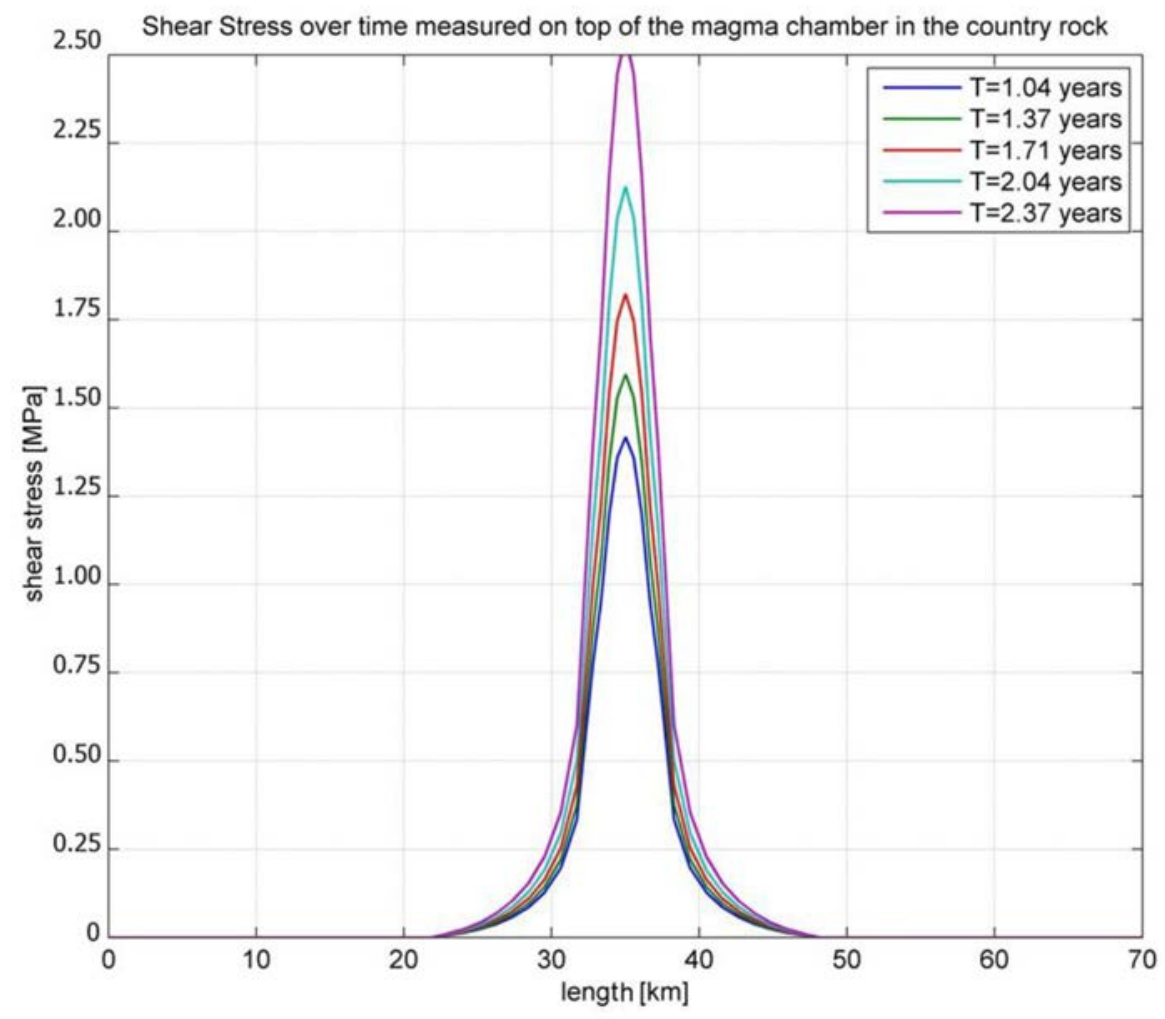

Figure 6 


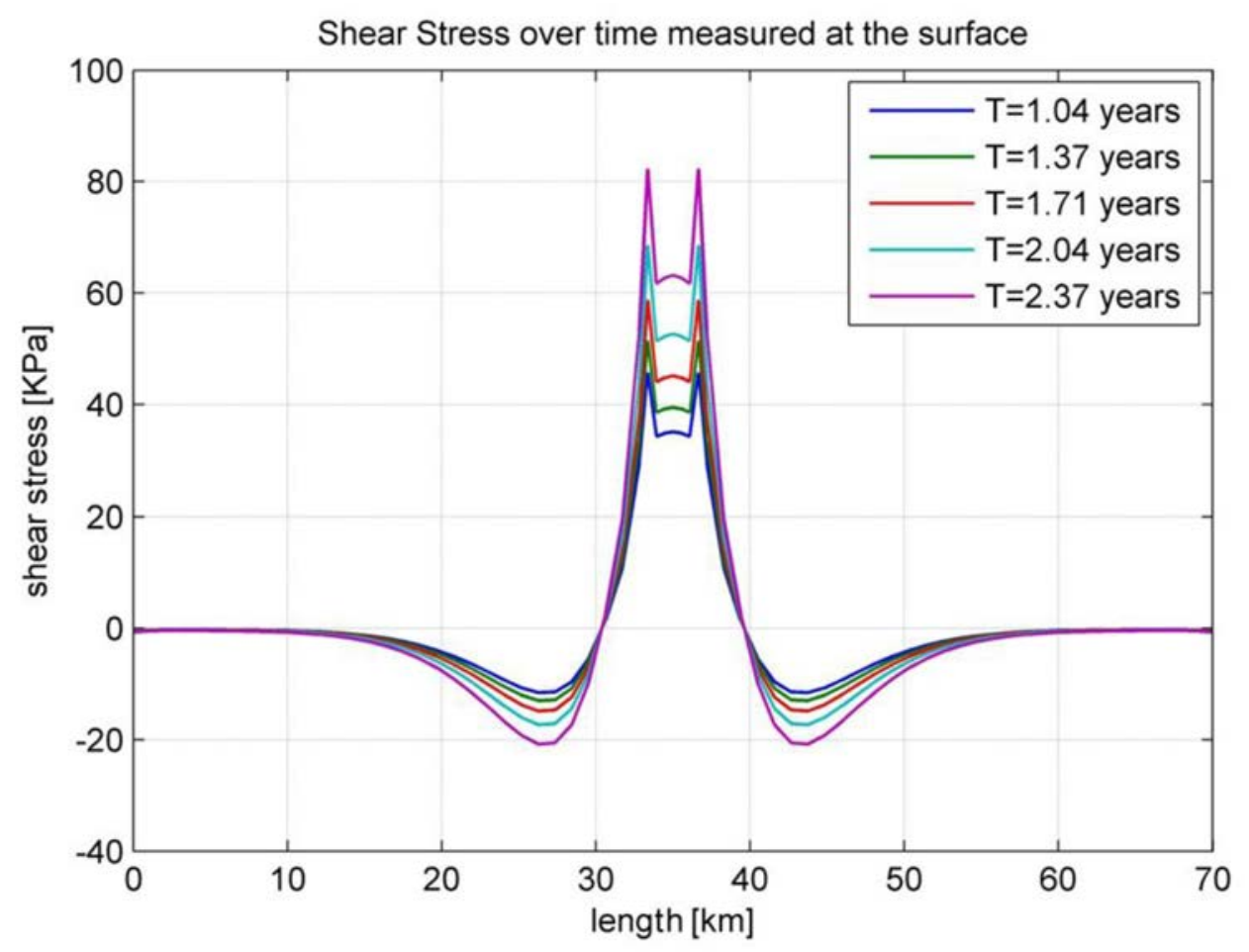

Figure 7

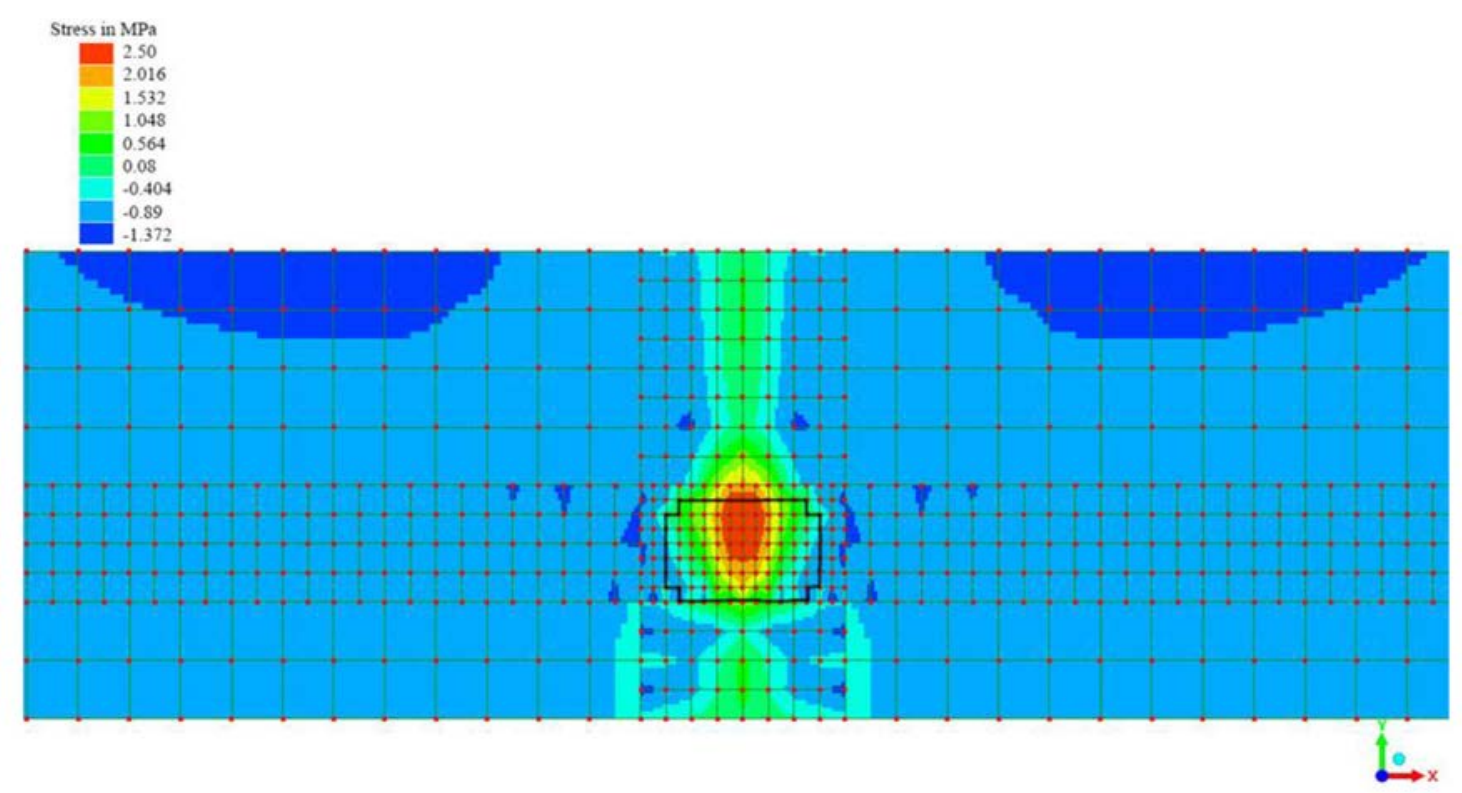

Figure 8 


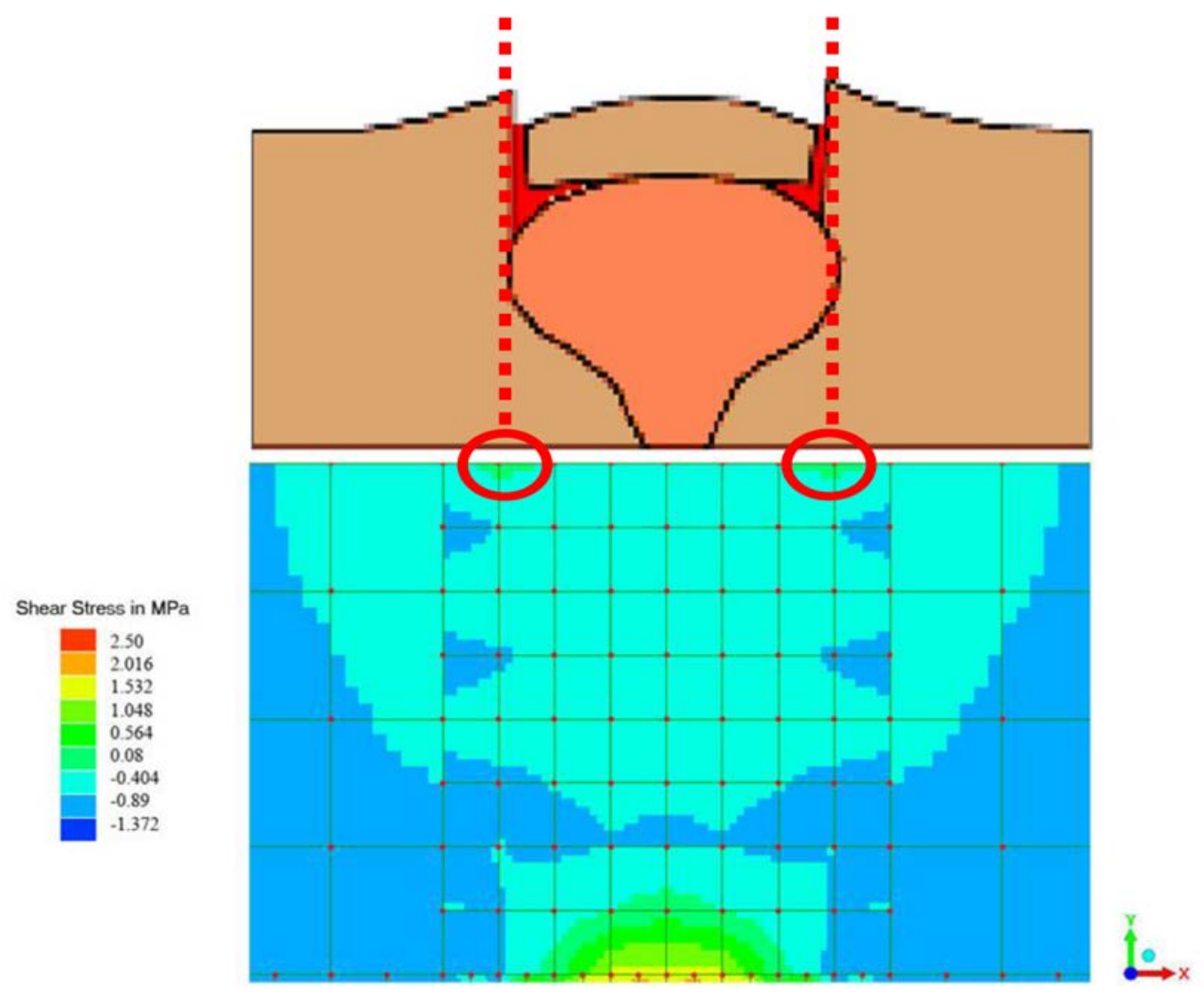

Figure 9. A, B, C
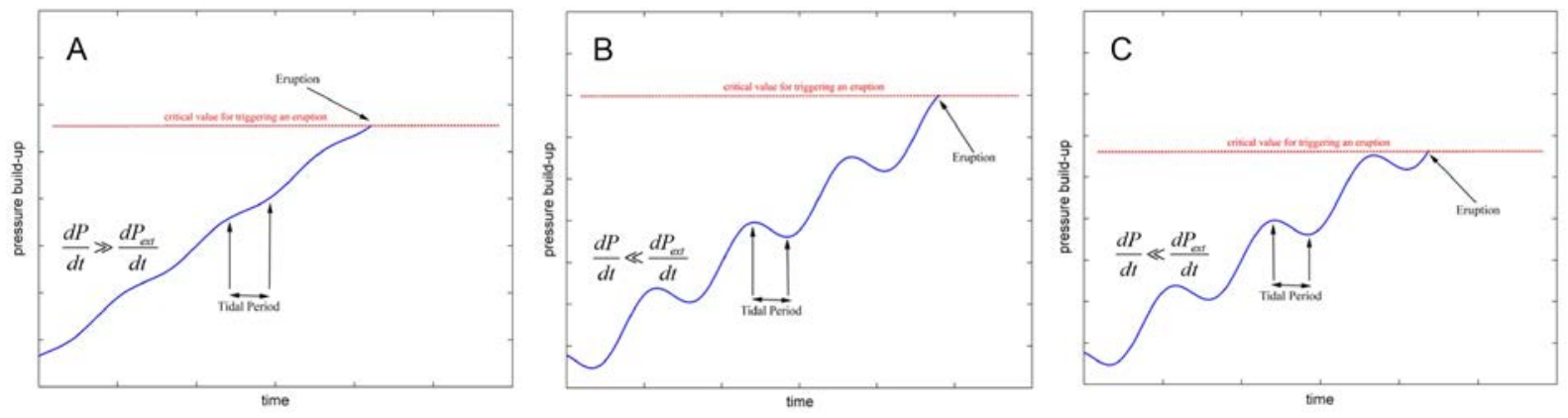